\title{
Microbulbifer hydrolyticus gen. nov., sp. nov., and Marinobacterium georgiense gen. nov., sp. nov., Two Marine Bacteria from a Lignin-Rich Pulp Mill Waste Enrichment Community
}

\author{
J. M. GONZÁLEZ, ${ }^{1}$ F. MAYER, ${ }^{2}$ M. A. MORAN, ${ }^{1,3}$ R. E. HODSON,,${ }^{1,3}$ AND W. B. WHITMAN ${ }^{1,3 *}$ \\ Department of Microbiology ${ }^{1}$ and Department of Marine Sciences and Institute of Ecology, ${ }^{3}$ University of Georgia, \\ Athens, Georgia 30602, and Institut für Mikrobiologie, Universität Göttingen, 37077 Göttingen, Germany ${ }^{2}$
}

\begin{abstract}
Two numerically important bacteria in marine pulp mill effluent enrichment cultures were isolated. These

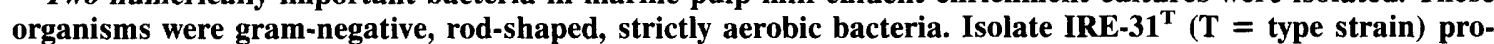
duced hydrolytic enzymes for the breakdown of cellulose, xylan, chitin, gelatin, and Tween 80 . It also utilized a variety of monosaccharides, disaccharides, amino acids, and volatile fatty acids for growth. Isolate $\mathrm{KW}-\mathbf{4 0} 0^{\mathrm{T}}$ did not utilize natural polymers, but it could grow on a variety of monosaccharides, disaccharides, alcohols, and amino acids. It also utilized methanol and aromatic compounds. The surfaces of both organisms were covered by blebs and vesicles. 16S rRNA analyses placed both organisms in the $\gamma-3$ subclass of the phylum Proteobacteria. They were related to Oceanospirillum linum, Marinomonas vaga, Pseudomonas putida, and Halomonas elongata, although a close association with any of these bacteria was not found. The guanine-pluscytosine contents of strain IRE-31 ${ }^{\mathrm{T}}$ and $\mathrm{KW}-40^{\mathrm{T}}$ were 57.6 and $54.9 \mathrm{~mol} \%$, respectively. On the basis of $16 \mathrm{~S}$ rRNA sequence and phenotypic characterizations, these isolates were different enough so that they could be considered members of new genera. Thus, the following two new genera and species are proposed: Microbulbifer hydrolyticus, with type strain IRE-31 (= ATCC 700072), and Marinobacterium georgiense, with type strain KW-40 (= ATCC 700074).
\end{abstract}

The complete degradation of lignin in natural environments involves numerous microorganisms, including both fungi and bacteria (36). Although most research on the biochemistry and genetics of lignin degradation has focused on fungi, bacteria are also capable of solubilizing, transforming, and mineralizing a variety of lignin preparations and lignin-like polymers and monomers (39). In certain environments, including anaerobic sediments, waterlogged wood $(27,28)$, and coastal seawater and sediments (4), bacterial lignin degradation may actually predominate over fungal degradation.

The pulp and paper industry is a major source of polymeric and highly recalcitrant lignin compounds entering the marine environment. A study conducted to assess the degradation potential of marine bacteria for pulp mill wastes rich in ligninrelated compounds led to the isolation of new prokaryotic organisms. These isolates were obtained from marine enrichment cultures in which the high-molecular-weight fraction of pulp mill waste, which is known to be slowly transformed biologically, was the sole carbon and energy source. Two isolates, IRE-31 ${ }^{\mathrm{T}}\left(\mathrm{T}=\right.$ type strain) and $\mathrm{KW}-40^{\mathrm{T}}$, contributed up to 23 and $2 \%$, respectively, of the pulp mill waste enrichment community DNA based on strain-specific oligonucleotide probes (13).

The phenotypic and phylogenetic characteristics showed that these isolates belong to previously undescribed genera of marine bacteria. We propose the names Microbulbifer hydrolyticus gen. nov., sp. nov., and Marinobacterium georgiense gen. nov., sp. nov., and designate IRE-31 and KW-40 the type strains, respectively.

${ }^{*}$ Corresponding author. Mailing address: Department of Microbiology, University of Georgia, Athens, GA 30602-2605. Phone: (706) 542-4219. Fax: (706) 542-2674. E-mail: whitman@uga.cc.uga.edu.

\section{MATERLALS AND METHODS}

Isolation. Isolates IRE- $31^{\mathrm{T}}$ and $\mathrm{KW}-40^{\mathrm{T}}$ were obtained from an enrichment community growing on the high-molecular-weight fraction of a black liquo sample from Federal Paper Board Company Inc., Augusta, Ga. The origina sample contained lignin-rich by-products from the pulping of southern United States hardwood species. The high-molecular-weight fraction was obtained by using tangential flow filtration through a cellulose membrane with an approximate exclusion size of 1,000 daltons (Pelicon; Millipore Corp., Bedford, Mass.) Approximately $4 \mathrm{~g}$ of the black liquor was dissolved in 2 liters of $0.1 \mathrm{M} \mathrm{NaOH}$ The solution was then continuously circulated through the membrane, and new $\mathrm{NaOH}$ solution was added until the $A_{280}$ of the filtrate was reduced from 0.2 to 0.02 . The absorbance of the concentrate indicated that $36 \%$ of the original material remained at the end of the filtration.

The enrichment medium consisted of 3 liters of filter-sterilized seawater

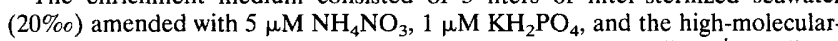
weight fraction of black liquor at a concentration of $20 \mathrm{mg} \mathrm{C} C$ liter $^{-1}$. Triplicate cultures in 6-liter flasks were inoculated with $20 \mathrm{ml}$ of freshly collected seawater from the salt marsh at Sapelo Island, Ga., that had been filtered through a $1-\mu \mathrm{m}$-pore-size Nuclepore filter and contained $5.6 \times 10^{5}$ bacterial cells $\mathrm{ml}^{-1}$, as determined by acridine orange direct counting (15). Due to the remoteness of the island, the seawater had no prior exposure to paper industry wastes. How ever, lignin-containing detritus was readily available from the cord grass Spartina alterniflora the predominant vegetation. At the time of collection, the water was cloudy and brown-green. After inoculation of the enrichment cultures, three subsequent transfers were carried out ( $20 \mathrm{ml}$ into 3 liters of fresh medium) a 2-week intervals. All of the flasks were incubated in the dark at room temperature with shaking at $100 \mathrm{rpm}$. The $\mathrm{pH}$ of the medium was the same as that of the original water $(\mathrm{pH} \mathrm{7.9)}$ and did not change during incubation. All of the glassware used for the enrichment cultures was combusted or treated with $10 \% \mathrm{HC}$ to avoid carbon contamination. At the end of the incubation, bacteria were isolated on YTSS agar plates (see below).

Media and culture conditions. YTSS agar contained $4 \mathrm{~g}$ of yeast extract (Difco Laboratories, Detroit, Mich.), $2.5 \mathrm{~g}$ of tryptone (Difco), $20 \mathrm{~g}$ of sea salts (Sigma Chemical Co, St. Louis, Mo.) $18 \mathrm{~g}$ of agar, and 1 liter of distilled water. The strains were stored in YTSS broth containing $15 \%$ glycerol and $15 \%$ dimethyl sulfoxide at $-70^{\circ} \mathrm{C}$ (YTSS broth was the same as YTSS agar except that agar was omitted). Other media used were marine agar 2216, marine broth 2216 (Difco) and marine salts basal medium (BM) (3) supplemented with various carbon sources. Unless specified otherwise, each carbon source was added at a concentration of $0.1 \%$ (wt/vol or vol/vol [for liquids]). BM agar was prepared by adding $18 \mathrm{~g}$ of agar per liter. Liquid cultures were grown at $25^{\circ} \mathrm{C}$ in the dark and at 300 $\mathrm{rpm}$ in a rotatory shaker. Plate cultures were grown at room temperature.

The ability to grow on various carbon sources was tested in $8 \mathrm{ml}$ of BM supplemented with $1 \mathrm{ml}$ of a mineral solution $\left(3.92 \mathrm{mg}\right.$ of $\mathrm{CuCl}_{2} \cdot 2 \mathrm{H}_{2} \mathrm{O}, 13.63$ $\mathrm{mg}$ of $\mathrm{ZnCl}_{2}, 1.3 \mathrm{mg}$ of $\mathrm{NiCl}_{2}, 11.06 \mathrm{mg}$ of $\mathrm{AlCl}_{3}, 3.82 \mathrm{mg}$ of $\mathrm{CoCl}_{2} \cdot 6 \mathrm{H}_{2} \mathrm{O}$, and 
$3.82 \mathrm{mg}$ of $\mathrm{H}_{3} \mathrm{BO}_{3}$ in $100 \mathrm{ml}$ of distilled $\mathrm{H}_{2} \mathrm{O}$ ) per liter and $1 \mathrm{ml}$ of a vitamin solution ( $2 \mathrm{mg}$ of biotin, $2 \mathrm{mg}$ of folic acid, $10 \mathrm{mg}$ of pyridoxine- $\mathrm{HCl}, 5 \mathrm{mg}$ of riboflavin, $5 \mathrm{mg}$ of thiamine, $5 \mathrm{mg}$ of nicotinic acid, $5 \mathrm{mg}$ of pantothenic acid, 0.1 $\mathrm{mg}$ of cyanocobalamin, and $5 \mathrm{mg}$ of $p$-aminobenzoic acid in $100 \mathrm{ml}$ of distilled $\mathrm{H}_{2} \mathrm{O} ; \mathrm{pH}$ adjusted to 7) per liter.

Morphological, biochemical, and physiological tests. The motility of exponential-phase cells was examined in BM containing succinic acid and in marine broth 2216 by the hanging drop method. Poly- $\beta$-hydroxybutyrate accumulation was determined by extraction of late-exponential-phase cultures in BM containing glucose (6). Pseudomonas cepacia that was grown in tryptic soy broth (Difco) served as a positive control. Production of bacteriochlorophyll $a$ was assayed as described by Ledyard et al. (19) by using Roseobacter denitrificans and Roseobacter litoralis as positive controls. Catalase production was assayed by using $0.3 \%$ hydrogen peroxide with a colony taken from $\mathrm{BM}$ containing yeast extract. Oxidase activity was determined by the method of Kovacs (16) by using colonies from the same plates.

Fermentation of D-glucose and denitrification were tested as described by Baumann and Baumann (3). Escherichia coli and Pseudomonas aeruginosa served as positive controls. Starch hydrolysis and Tweenase 80 , gelatinase, and chitinase activities were assayed as described by Baumann and Baumann (3). Agarase activity was assayed as described by Smibert and Krieg (30). Growth under anaerobic conditions was tested on marine agar 2216 in a GasPak system (BBL Cockeysville, Md.).

Susceptibilities to inhibitors were determined on BM agar containing yeast extract by using susceptibility disks (Difco). Resistance was defined as confluen growth up to the edge of a disk.

To test for growth on various carbon sources, an inoculum was grown to an $A_{540}$ of approximately 1 in BM containing yeast extract, and the inoculum size was $2.5 \%$. A test was considered positive when turbidity was visible after three transfers (2.5\% each). Growth without vitamins was also tested in BM containing glucose, acetate, citrate, or glutamate. In some experiments, the vitamin solution was replaced with a solution containing $100 \mathrm{mg}$ of thiamine, $100 \mathrm{mg}$ of nicotinic acid, $100 \mathrm{mg}$ of pantothenic acid, and $1 \mathrm{mg}$ of biotin in $100 \mathrm{ml}$ of distilled $\mathrm{H}_{2} \mathrm{O}$ Incubations were performed in duplicate in the dark at $25^{\circ} \mathrm{C}$. In the case of aromatic compounds, the disappearance and transformation of the substrate in the supernatant were monitored spectrophotometrically. When there was no growth, the substrate was tested for toxicity by adding yeast extract to a final concentration of $0.1 \%(\mathrm{wt} / \mathrm{vol})$

Degradation of birchwood xylan (Sigma) was tested on solid and in liquid BM containing $0.5 \%$ xylan as the sole carbon source. Degradation of cellulose was tested on BM agar containing $0.5 \%$ Avicel (microcrystalline cellulose type $\mathrm{PH}$ 105; FMC Corp. Philadelphia, $\mathrm{Pa}$ ), 60-mesh cotton, or 60-mesh Whatman no. 1 paper along with $0.2 \%$ cellobiose as a second carbon source or on BM agar containing $0.5 \%$ carboxymethyl cellulose (Sigma) as the sole carbon source After 1 week of incubation at $37^{\circ} \mathrm{C}$, the Congo red test (29) was performed.

The growth responses to temperature and sea salts were measured in $\mathrm{BM}$ containing yeast extract and in $\mathrm{BM}$ containing glucose at $25^{\circ} \mathrm{C}$, respectively. The growth response to $\mathrm{NaCl}$ was measured in $\mathrm{BM}$ containing $0.2 \%$ yeast extract at $37^{\circ} \mathrm{C}$. The response to $\mathrm{pH}$ was determined in $\mathrm{BM}$ containing glucose at $25^{\circ} \mathrm{C}$. The $\mathrm{pH}$ was adjusted with $10 \mathrm{M} \mathrm{HCl}$ or $10 \mathrm{M} \mathrm{NaOH}$. To determine the temperature response, inocula were adapted by growing them within 5 to $6^{\circ} \mathrm{C}$ of the temperature being tested. To determine the sea salts response, inocula were grown in media containing either twice or one-half the tested concentration of sea salts. To determine the $\mathrm{pH}$ response, the inocula were grown in media having $\mathrm{pH}$ values within $1 \mathrm{pH}$ unit of the $\mathrm{pH}$ being tested. To determine the $\mathrm{NaCl}$ response, the initial inoculum was grown in the presence of $0.2 \mathrm{M} \mathrm{NaCl}$. Growth rates at other $\mathrm{NaCl}$ concentrations were determined following stepwise transfers to the higher and lower concentrations tested. For instance, the initial culture was used to inoculate media containing 0.1 and $0.25 \mathrm{M} \mathrm{NaCl}$, the culture containing 0.25 $\mathrm{M} \mathrm{NaCl}$ was used to inoculate a culture containing $0.5 \mathrm{M} \mathrm{NaCl}$ and the culture containing $0.1 \mathrm{M} \mathrm{NaCl}$ was used to inoculate a culture containing $0.01 \mathrm{M} \mathrm{NaCl}$. In every case, the transfer was performed during exponential growth. To determine if $\mathrm{NaCl}$ was required for growth, it was replaced with equimolar concen trations of $\mathrm{KCl}$ or $\mathrm{LiCl}$. Growth was monitored by determining the $A_{540}$.

Potential nitrogen sources for growth were tested on BM containing glucose without $\mathrm{NH}_{4} \mathrm{Cl}$. Media containing an equimolar concentration of $\mathrm{KNO}_{3}, 0.1 \%$ Casamino Acids, or no fixed nitrogen were then tested.

The effect of preexposure to $\mathrm{Mg}^{2+}$ or $\mathrm{Na}^{+}$ions on lysis in distilled water was studied by using cells from the exponential growth phase cultured in BM containing $0.2 \%$ yeast extract. The cells were washed three times in $50 \mathrm{mM}$ Tris chloride (pH 7.5) buffer containing $0.5 \mathrm{M} \mathrm{NaCl}$ or $0.05 \mathrm{M} \mathrm{MgCl}_{2}$ and then resuspended in distilled water to an $A_{450}$ of 0.1 (17). Lysis was recorded for $1 \mathrm{~h}$.

Electron microscopy. The cells were grown in BM containing $0.2 \%$ glucose and $0.01 \%$ yeast extract. Negative staining was performed with an aqueous solution $(2 \%, \mathrm{wt} / \mathrm{vol})$ of phosphotungstic acid adjusted to $\mathrm{pH} 7.0$ as described previously $(1,25)$. Ultrathin sectioning was performed by previously described procedures (37). Electron micrographs were taken with a Philips model EM 301 instrument operated at an acceleration voltage of $80 \mathrm{kV}$

DNA base composition. The isolates were grown in marine broth 2216 , and DNA was extracted by an $\mathrm{NaOH}$ procedure $(20)$. The DNA was desalted by using Wizard DNA clean-up minicolumns (Promega Biological Research Prod- ucts, Madison, Wis.). The base composition was determined as described by Mesbah et al. (20).

Cellular fatty acid analysis. Fatty acid methyl ester analyses were performed at Microbial ID Inc. Newark. Del. The isolates were grown on marine aga 2216. Briefly, cells were saponified in $1.0 \mathrm{ml}$ of reagent $1(15 \mathrm{~g}$ of $\mathrm{NaOH}, 50 \mathrm{ml}$ of methanol, $50 \mathrm{ml}$ of water) at $100^{\circ} \mathrm{C}$ for $30 \mathrm{~min}$ prior to methylation with 1.5 $\mathrm{ml}$ of reagent $2(325 \mathrm{ml}$ of $6 \mathrm{M} \mathrm{HCl}, 275 \mathrm{ml}$ of methanol). Following extraction, the fatty acid methyl esters were analyzed by gas chromatography.

DNA extraction and sequencing of $16 \mathrm{~S}$ ribosomal DNA. DNA was extracted by the method of Tsai and Olson (34). Primers were used to amplify overlapping portions of the 16S rRNA gene by PCR. Each PCR mixture contained 50 ng of DNA, $0.35 \mathrm{mM} \mathrm{MgCl}_{2}$, each deoxyribonucleoside triphosphate at a concentration of $70 \mu \mathrm{M}$, each primer at a concentration of $50 \mathrm{nM}$, and $1 \mathrm{U}$ of Taq DNA polymerase (Promega) in a total volume of $100 \mu \mathrm{l}$. After a hot start at $82^{\circ} \mathrm{C}$ for $10 \mathrm{~min}$, the PCR cycle parameters were as follows: preheating for 3 min at $94^{\circ} \mathrm{C}$ denaturation at $94^{\circ} \mathrm{C}$ for $1 \mathrm{~min}$, annealing at $45^{\circ} \mathrm{C}$ for $1 \mathrm{~min}$, and extension for 2 $\min$ at $72^{\circ} \mathrm{C}$. After 45 cycles, the PCR products were analyzed in $3 \%(\mathrm{wt} / \mathrm{vol})$ agarose to confirm their size and purity, then extracted with phenol, phenol chloroform, and chloroform, and precipitated with isopropanol. The primer used for PCR were as follows: (E. coli numbering) 10F (AGTTTGATCCTGG CTC) (33), 68F (TNANACATGCAAGTCGAKCG), 338F (GCTGCCTCCCG TAGGAGT), 338R (ACTCCTACGGGAGGCAGC) (31), 785F (GGATTAG ATACCCNGGTA) (5), 926R (CCGTCAATTCMTTTGAGTTT), 926F (AAACTCAAAKGAATTGACGG), 1406R (ACGGGCGGTGTGTRC) (18), and 1524R (AAGGAGGTGATCCAGCC) ( $\mathrm{K}$ is $\mathrm{G}$ or T, R is A or G, W is A or $\mathrm{T}, \mathrm{M}$ is $\mathrm{A}$ or $\mathrm{C}$, and $\mathrm{N}$ is any base).

The sequence of each PCR product was determined in both directions with an automated sequencer at the University of Georgia Molecular Genetics Instrumentation Facility. The secondary structures of 600 bases of each sequence were constructed manually and compared with the secondary structure of $E$. coli to look for amplification or sequencing mistakes.

Comparative analysis of $16 \mathrm{~S}$ ribosomal DNA. Evolutionary distances were calculated from the aligned sequences by using the Jukes-Cantor correction (positions containing base ambiguities, deletions, or insertions were not considered) and the PHYLIP package (8). Phylogenetic trees and a bootstrap analysis were performed with the PHYLIP package and the PAUP version 3.0 package (32) by using the neighbor-joining and unweighted pair group with mathematical average (UPGMA) methods. Parsimony and Lake's invariant analyses were performed by using the PAUP version 3.1 package. The maximum-likelihood method used was the method in the PHYLIP package. Parsimony trees were constructed by using the heuristic method. In every case, the trees were unrooted and contained different outgroups for comparison.

Nucleotide sequence accession numbers. The $16 \mathrm{~S}$ rRNA sequences of strain IRE- $31^{\mathrm{T}}$ and $\mathrm{KW}-40^{\mathrm{T}}$ have been assigned GenBank accession numbers U58338 and U58339, respectively. The accession numbers of the other sequences uscd to construct phylogenetic trees are as follows: Alteromonas macleodii, L10938: Antarctic gas vacuolate bacterium (14), U14581; Bacillus subtilis, X60646; E. coli J01859; Halomonas meridiana, M93356; Halovibrio variabilis, M93357; Mari nobacter hydrocarbonoclasticus, X67022; Methylococcus capsulatus, X72771; $P$. aeruginosa, M34133; Pseudomonas flavescens, U01916; Pseudomonas mendocina, L37366; Pseudomonas putida, L37365; and Pseudomonas stutzeri, U26261.

\section{RESULTS}

Isolation. Isolates IRE- $31^{\mathrm{T}}$ and $\mathrm{KW}-40^{\mathrm{T}}$ were obtained from single colonies on YTSS medium following the third transfer of the pulp mill waste enrichment culture. Both strains were judged to be pure after the isolated colonies were restreaked on YTSS medium more than five times.

Cellular and colonial morphology. Light microscopic examination revealed that the cells of strain IRE $-31^{\mathrm{T}}$ were straight rods which stained gram negative and were 1.1 to $1.7 \mu \mathrm{m}$ long and 0.3 to $0.5 \mu \mathrm{m}$ in diameter. In most media and suspensions of colonies, strain IRE-31 $31^{\mathrm{T}}$ appeared as single cells. However, in BM containing $0.5 \%$ xylan, the cells formed long chains. In marine broth the cells formed shorter chains. After 1 week colonies on complex or defined media were $1 \mathrm{~mm}$ or less in diameter, circular, convex with entire margins, and cream colored.

Electron microscopic analyses confirmed the cell morphology, size, and type of cell wall (Fig. 1a and g). In addition, both in negatively stained samples (Fig. 1a and b) and in ultrathin sections (Fig. 1e), the cell surface appeared to be covered by blebs and vesicles formed by local extensions of the peripheral wall layers, without involvement of the cytoplasmic membrane. High magnification revealed that these blebs and vesicles were 

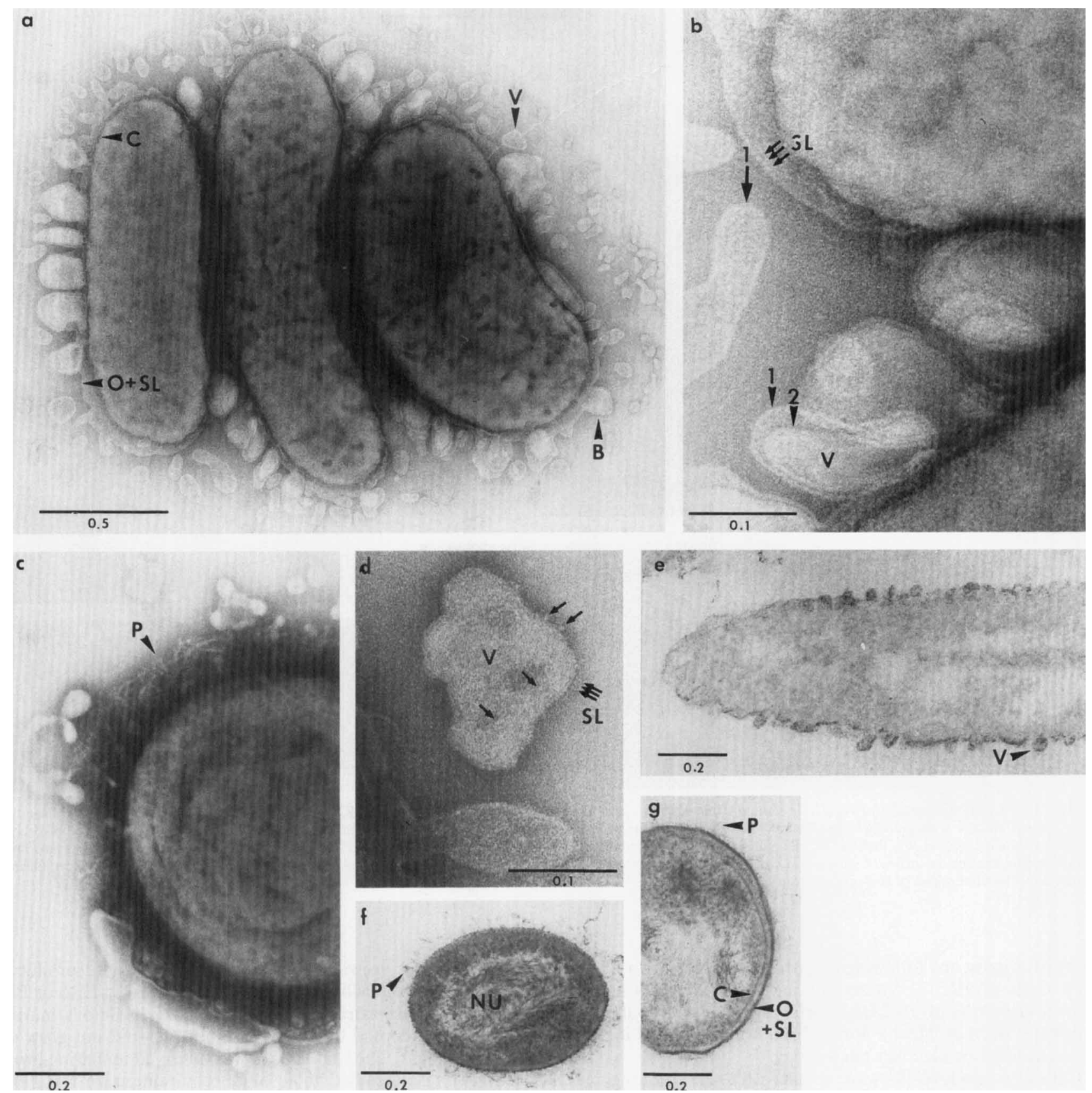

FIG. 1. Electron micrographs of negatively stained strain IRE-31 ${ }^{\mathrm{T}}$ (a to d) and ultrathin sections of strain IRE- $31^{\mathrm{T}}$ (e to g). (a) Group of single cells. The cell surfaces are covered by blebs (B) and vesicles (V) which are formed by local extensions of the outer membrane (O) and S-layer (SL). The cytoplasmic membrane (C) is not involved in the formation of blebs and vesicles. (b) Higher magnification of an area shown in panel a. Vesicles (V) and blebs may be composed of one (arrow 1) or two (arrowheads 1 and 2) concentric layers. The outermost wall layer exhibits structural features typical of S-layers (SL) (i.e., orderly arranged units forming a monolayer). (c) Cells may be covered by a dense network of fine fibrils (P). (d) The S-layer (SL) of vesicles (V) may be partially degraded; the remnants (unlabeled arrows) are still attached to the supporting layer (most probably vesiculated outer membrane). (e) Vesicles (V) and blebs in a chemically fixed, ultrathin section of a cell. (f) Ultrathin section, showing a cover composed of thin fibers (P). NU, nucleoid. (g) Cross section revealing the gram-negative type of cell wall. SL, S-layer; C cytoplasmic membrane; $\mathrm{O}$, outer membrane; $\mathrm{P}$, fine fibers. The dimensions of bars are given in micrometers.

made up of one or two concentric layers (Fig. $1 \mathrm{~b}$ and d). As described by Forsberg et al. (9), the outer membrane did not strongly adhere to the peptidoglycan layer (Fig. 1a and b), suggesting a possible mechanism of vesicle formation. The outermost wall layer was composed of regularly arranged units, a feature typical of surface layers (S-layers) (Fig. 1b). Units of this type, in more or less nonordered fashion, also covered free vesicles (Fig. 1d), which presumably were formed by the outer membrane. The loss of order in the S-layer was probably caused by partial degradation. An additional structural aspect seen after negative staining (Fig. 1c) and ultrathin sectioning (Fig. 1f) was that many of the cells were covered by a dense network of thin fibers, presumably consisting of polysaccharides. This capsular material was also visualized by phase- 

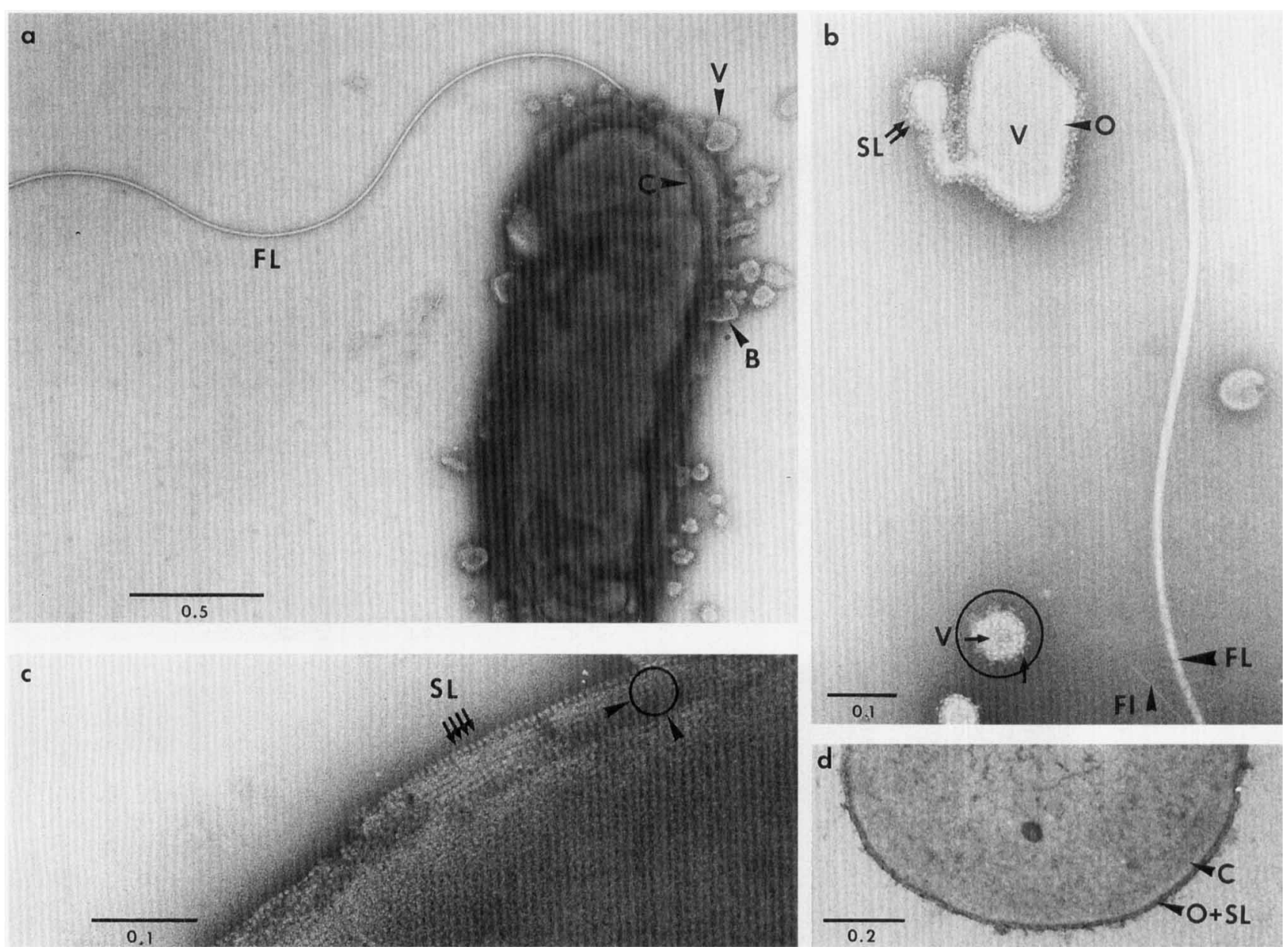

FIG. 2. Electron micrographs of negatively stained strain $\mathrm{KW}-40^{\mathrm{T}}$ (a to c) and an ultrathin section of strain $\mathrm{KW}-40^{\mathrm{T}}$ (d). (a) Cell with a polarly inserted flagellum (FL). The cell surface is covered by blebs (B) and vesicles (V). C, cytoplasmic membrane. (b) Vesicles (V) which consist of outer membrane (O) with attached S-layer (SL and unlabeled arrow). FI, fimbria; FL, flagellum. (c) High magnification of the S-layer (SL) covering cells of strain KW-40 ${ }^{\mathrm{T}}$. A portion of the surface layer demonstrating the regular array of subunits is circled. (d) Cross section showing the outer membrane (O) and the S-layer (SL) closely associated. C, cytoplasmic membrane. The dimensions of bars are given in micrometers.

contrast microscopy following negative staining with India ink (21). Cells of IRE-31 $1^{\mathrm{T}}$ were not motile during exponential growth in marine broth 2216 , marine agar, or BM containing succinate. Neither flagella nor fimbriae were detected in samples inspected by electron microscopy.

Cells of strain $\mathrm{KW}-40^{\mathrm{T}}$ were motile, 1.6 to $2.3 \mu \mathrm{m}$ long, and 0.5 to $0.7 \mu \mathrm{m}$ in diameter. They stained gram negative. After 1 week of incubation, colonies of strain $\mathrm{KW}-40^{\mathrm{T}}$ on complex or defined medium were $0.5 \mathrm{~mm}$ or less in diameter, circular, convex with entire margins, and translucent.

Electron microscopy of strain $\mathrm{KW}-40^{\mathrm{T}}$ confirmed the type of cell wall (Fig. 2). As observed in samples of strain IRE-31 ${ }^{\mathrm{T}}$, numerous blebs and vesicles covered the surfaces of the cells (Fig. 2a). The outer membrane did not strongly adhere to the peptidoglycan layer (Fig. 2a). The cell wall (Fig. 2c) and the surfaces of the blebs and vesicles (Fig. 2b) were covered by an S-layer that was not clearly visible in ultrathin sections (Fig. 2d). A number of cells had a single polarly inserted flagellum (Fig. 2a and b) and fimbriae (Fig. 2b). Thin fibers, presumably consisting of polysaccharides, were also present at the cell surface, but they were not a prominent structural feature. A distinct capsule was not observed by phase-contrast microscopy and negative staining.
Culture and growth conditions. Neither isolate produced fluorescent or diffusible pigments on marine agar 2216 or BM containing yeast extract. The isolates grew in Shioi's marine medium, as adapted by Shiba (26), but they did not grow on tryptic soy agar. The best growth was observed in marine broth 2216. Both isolates had an absolute requirement for $\mathrm{NaCl}$ and failed to grow when $\mathrm{NaCl}$ was replaced with $\mathrm{KCl}$ or $\mathrm{LiCl}$. Cells of both strains lysed in distilled water if the cells were first washed with $0.5 \mathrm{M} \mathrm{NaCl}$, while washing with $0.05 \mathrm{M} \mathrm{MgCl}_{2}$ prevented lysis; this response is common among bacteria isolated from marine environments $(17,24)$.

The growth of both isolates in defined medium was considerably enhanced by the addition of $0.005 \%$ yeast extract or a vitamin solution. When each of the vitamins in the vitamin solution was added singly, growth was not enhanced. Similarly, the addition of a combination of thiamine, nicotinic acid, pantothenic acid, and biotin had no effect. Growth was also enhanced by vigorous shaking.

Both isolates exhibited similar growth rates and had similar final cell densities in BM containing yeast extract and $0.1,0.25$, 0.5 , or $1 \times$ sea salts. Optimal growth of isolate IRE- $31^{\mathrm{T}}$ was observed in the presence of 0.1 to $0.5 \mathrm{M} \mathrm{NaCl}$ (Fig. 3A). Growth occurred in the presence of $\mathrm{NaCl}$ concentrations rang- 

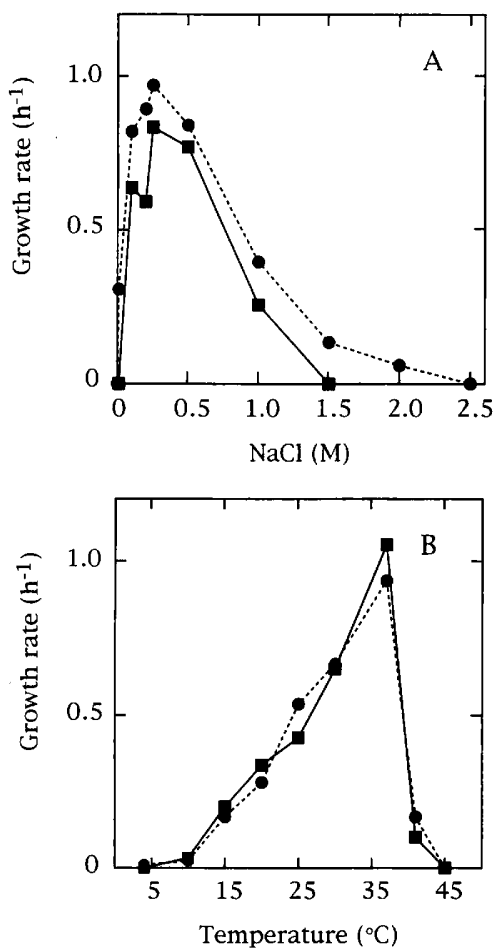

FIG. 3. Growth responses of strain IRE-31 ${ }^{\mathrm{T}}(\mathbf{D})$ and strain $\mathrm{KW}-40^{\mathrm{T}}(\bullet)$ to different $\mathrm{NaCl}$ concentrations (A) and temperatures (B).

ing from 0.1 to $1 \mathrm{M}$ but not in the presence of 0.01 or $1.5 \mathrm{M}$ $\mathrm{NaCl}$. The temperature range for growth was 10 to $41^{\circ} \mathrm{C}$, and the optimum temperature was $37^{\circ} \mathrm{C}$ (Fig. 3B). Isolate IRE-31 ${ }^{\mathrm{T}}$ grew in $\mathrm{BM}$ containing glucose medium at $\mathrm{pH} 6.5$ to 8.5 . It did not grow at $\mathrm{pH} 5.5$ or 9.5 , and optimal growth was observed at $\mathrm{pH} 7.5$.

The optimal $\mathrm{NaCl}$ concentration for growth of isolate $\mathrm{KW}$ $40^{\mathrm{T}}$ was 0.1 to $0.5 \mathrm{M}$ (Fig. $3 \mathrm{~A}$ ). Growth was also observed in the presence of 0.01 and $2 \mathrm{M} \mathrm{NaCl}$. The temperature range for growth was 4 to $41^{\circ} \mathrm{C}$, and the optimum temperature was $37^{\circ} \mathrm{C}$ (Fig. 3B). KW-40 ${ }^{\mathrm{T}}$ grew at $\mathrm{pH} 5.5$ to 9.5 , and optimal growth occurred at $\mathrm{pH} 7.5$.

Physiological and biochemical characteristics. Both isolates were catalase and oxidase positive. They did not form acid from glucose, did not reduce nitrate, and failed to grow under anaerobic conditions on marine agar 2216. They did not grow on plates of $\mathrm{BM}$ containing glucose without a source of fixed nitrogen. Although $\mathrm{KNO}_{3}$ or Casamino Acids could substitute for $\mathrm{NH}_{4} \mathrm{Cl}$, considerably better growth was obtained when $\mathrm{NH}_{4} \mathrm{Cl}$ was the nitrogen source. Strain IRE-31 ${ }^{\mathrm{T}}$ utilized the following compounds for growth: glucose, $\mathrm{N}$-acetyl-D-glucosamine, cellobiose, xylose, pyruvate, acetate, propionate, butyrate, succinate, malate, DL- $\beta$-hydroxybutyrate, L-alanine, L-arginine, L-glutamate, L-glutamine, L-histidine, L-leucine, L-proline, L-serine, L-threonine, ferulate, and vanillate. The substances not utilized for growth included sucrose, fructose, mannose, rhamnose, lactose, glycerol, citrate, phenol, benzoate, $p$-hydroxybenzoate, benzene, salycilate, $p$-coumarate, cinnamate, formate, methanol, methylamine, ethanol, 1-propanol, 1-butanol, 2-propanol, L-asparagine, L-aspartate, glycine, L-isoleucine, L-lysine, L-methionine, L-phenylalanine, L-tryptophan, and L-valine. Even though strain IRE- $31^{\mathrm{T}}$ utilized a limited number of carbohydrates, it was able to hydrolyze chitin, gelatin, Tween 80 , and starch, but not agar.
Strain IRE-31 ${ }^{\mathrm{T}}$ hydrolyzed cellulose and birchwood xylan. When the Congo red test was applied to colonies grown on medium containing Avicel, Whatman no. 1 paper, cotton, or carboxymethyl cellulose, clear zones were observed. Following growth on birchwood xylan, clear areas around the colonies were also observed. In liquid medium, strain IRE- $31^{\mathrm{T}}$ cleared BM containing $0.5 \%$ xylan. As determined by phase-contrast microscopy, cells did not appear to attach to birchwood xylan particles. However, the cell arrangement changed from single cells to chains.

Strain IRE-31 ${ }^{\mathrm{T}}$ was resistant to penicillin $\mathrm{G}(10 \mathrm{U})$, streptomycin $(10 \mu \mathrm{g})$, and vancomycin $(30 \mu \mathrm{g})$ and was susceptible to tetracycline $(30 \mu \mathrm{g})$, kanamycin $(30 \mu \mathrm{g})$, chloramphenicol $(30 \mu \mathrm{g})$, and ampicillin $(10 \mu \mathrm{g})$.

Strain KW- $40^{\mathrm{T}}$ grew on the following carbon sources: glucose, fructose, mannose, cellobiose, xylose, glycerol, pyruvate, formate, acetate, propionate, butyrate, succinate, malate, DL$\beta$-hydroxybutyrate, citrate, methanol, methylamine, ethanol, 1-propanol, 2-propanol, 1-butanol, L-alanine, L-aspartate, Lasparagine, L-glutamate, L-glutamine, L-lysine, L-phenylalanine, L-proline, phenol, benzoate, $p$-hydroxybenzoate, $p$ coumarate, cinnamate, ferulate, and vanillate. The substances not utilized for growth included sucrose, rhamnose, lactose, benzene, salycilate, $\mathrm{N}$-acetyl-D-glucosamine, L-arginine, glycine, L-histidine, L-isoleucine, L-leucine, L-methionine, L-serine, L-threonine, L-tryptophan, and L-valine. Isolate $\mathrm{KW}-40^{\mathrm{T}}$ hydrolyzed Tween 80 but not chitin, gelatin, starch, or agar.

Strain KW- $40^{\mathrm{T}}$ did not hydrolyze any of the cellulosic compounds tested or xylan.

Strain $\mathrm{KW}-40^{\mathrm{T}}$ was resistant to penicillin $\mathrm{G}(10 \mathrm{U})$ and vancomycin $(30 \mu \mathrm{g})$ and was susceptible to tetracycline $(30$ $\mu \mathrm{g})$, streptomycin $(10 \mu \mathrm{g})$, kanamycin $(30 \mu \mathrm{g})$, chloramphenicol $(30 \mu \mathrm{g})$, and ampicillin $(10 \mu \mathrm{g})$.

Neither isolate accumulated poly- $\beta$-hydroxybutyrate, nor did the isolates produce bacteriochlorophyll $a$ in marine broth 2216 in the dark.

G $+\mathbf{C}$ contents of DNAs. The guanine-plus-cytosine $(\mathrm{G}+\mathrm{C})$ content of strain IRE-31 $1^{\mathrm{T}}$ DNA was $57.6 \pm 0.3$ mol\% (mean \pm standard deviation; $n=6$ ), and the $\mathrm{G}+\mathrm{C}$ content of strain $\mathrm{KW}-40^{\mathrm{T}}$ DNA was $54.6 \pm 0.3 \mathrm{~mol} \%(n=6)$.

Cellular fatty acids. Following saponification, the following major fatty acids were detected in strain IRE-31 ${ }^{\mathrm{T}}$ : 15:0 iso, $26.2 \% ; 17: 1$ iso $\omega 9 \mathrm{c}, 25.4 \% ; 11: 0$ iso $3 \mathrm{OH}, 5.6 \% ; 11: 0$ iso $5.0 \% ; 17: 0$ iso, $4.6 \% ; 15: 0,2.7 \% ; 17: 1 \omega 8 \mathrm{c}, 1.8 \%$; and $17: 0$ $1.5 \%$. This bacterium also contained the following major fatty acids, whose levels were not determined due to poor resolution of the chromatography system: $18: 1 \omega 7 \mathrm{c}, 18: 1 \omega 9 \mathrm{t}, 18: 1 \omega 12 \mathrm{t}$ $16: 1 \omega 7 \mathrm{c}$, and 15 iso $2 \mathrm{OH}$. Strain $\mathrm{KW}-40^{\mathrm{T}}$ contained the following major fatty acids: $16: 0,27.2 \% ; 10: 03 \mathrm{OH}, 5.5 \% ; 10: 0$, $2.7 \% ; 12: 0,1.6 \%$; and $18: 0,1.2 \%$. In addition, the major fatty acids whose levels were not determined due to poor resolution of the chromatography system were $18: 1 \omega 7 \mathrm{c}, 18: 1 \omega 9 \mathrm{t}, 18: 1$ $\omega 12 \mathrm{t}, 16: 1 \omega 7 \mathrm{c}$, and 15 iso $2 \mathrm{OH}$.

Molecular phylogenetic analysis. The sequence of an approximately 1,400 -bp portion of the $16 \mathrm{~S}$ rRNA gene was obtained for each isolate. No sequence available in the GenBank database exhibited more than $91 \%$ similarity with the sequence of either isolate. Parsimony and neighbor-joining analyses performed with representatives of the eubacterial and archaebacterial groups placed both strains in the $\gamma$ subclass of the Proteobacteria, close to the true pseudomonads in subgroup $\gamma-3$ $(22,38)$. Strains IRE- $31^{\mathrm{T}}$ and $\mathrm{KW}-40^{\mathrm{T}}$ exhibited an average of $91 \%$ and less than $90 \%$ sequence similarity, respectively, with the true pseudomonads and other members of this group (Fig. 4 and data not shown). Moreover, the level of similarity between strains IRE- $31^{\mathrm{T}}$ and $\mathrm{KW}-40^{\mathrm{T}}$ was only $88 \%$. 


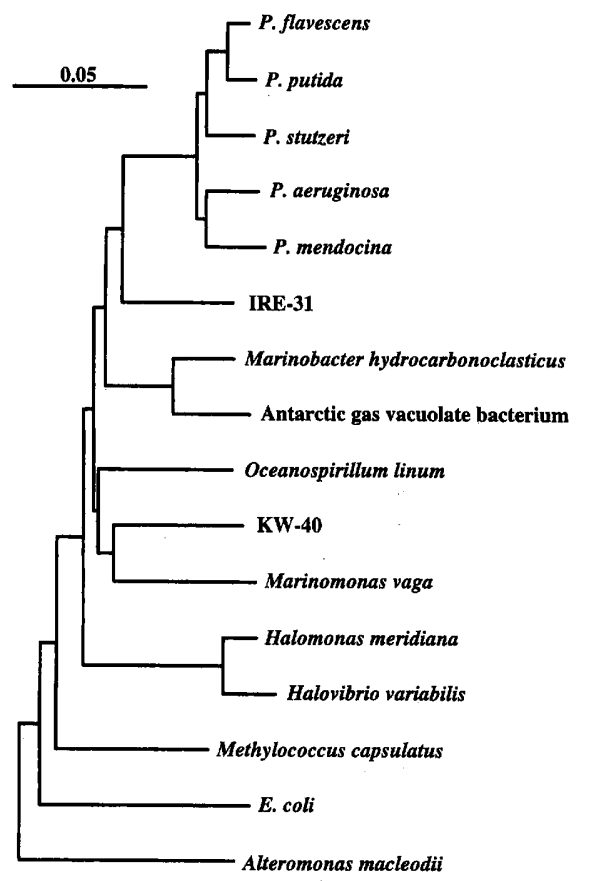

FIG. 4. Phylogeny of strain IRE-31 ${ }^{\mathrm{T}}$ and strain $\mathrm{KW}-40^{\mathrm{T}}$ based on $16 \mathrm{~S}$ rRNA. Representatives of the most closely related groups in the $\gamma$ subclass of the Proteobacteria are included for comparison. The dendrogram was constructed by analyzing approximately $1,400 \mathrm{bp}$ of the sequence with the neighbor-joinin method contained in the PHYLIP package. The tree was unrooted with Bacillus subtilis as the outgroup. Bar = Jukes-Cantor distance of 0.05 .

Phylogenetic analyses performed with partial and nearly complete sequences of members of closely related genera failed to detect a robust association for either isolate. The clustering determined by the parsimony method was similar to the clustering determined by the neighbor-joining or UPGMA method (data not shown). Strain IRE-31 ${ }^{\mathrm{T}}$ was most closely associated with the pseudomonads, and strain $\mathrm{KW}-40^{\mathrm{T}}$ was most closely associated with Marinomonas vaga. However, a bootstrap analysis in which neighbor joining was used gave values around $70 \%$ in both cases. When parsimony was used, the bootstrap values were less than $50 \%$ in both cases. Thus, the association of strain IRE-31 $1^{\mathrm{T}}$ with the pseudomonad group and the association of strain $\mathrm{KW}-40^{\mathrm{T}}$ with Marinomonas vaga were not strong. Similarly, the association of strain IRE-31 ${ }^{\mathrm{T}}$ with the pseudomonads and the association of strain $\mathrm{KW}-40^{\mathrm{T}}$ with Marinomonas vaga were not observed when only positions from a more conserved domain, domain II of the $16 \mathrm{~S}$ rRNA, were analyzed by the parsimony, neighbor-joining, and UPGMA methods (35). Associations were also not observed when Lake's invariant method was used with either domain II or complete sequences. Likewise, maximum-likelihood analyses of the complete and domain II sequences yielded different clusters despite the fact that all branches on the tree were significantly positive at $P<0.01$. Thus, neither isolate appeared to be strongly affiliated with any of the previously described genera in the $\gamma-3$ subgroup.

\section{DISCUSSION}

Both isolates possessed a wide range of catabolic activities that might explain their abundance in the pulp mill waste enrichment culture. Isolate IRE- $31^{\mathrm{T}}$ hydrolyzed natural polymers like cellulose and hemicellulose that might be compo- nents of the enrichment culture carbon source. Although KW$40^{\mathrm{T}}$ did not utilize these polymers, it catabolized lignin-related acids ( $p$-coumarate, cinnamate, ferulate, and vanillate) and methanol, all of which could be derived from lignin by biological and/or chemical processes. Both isolates also utilized a variety of sugars, organic acids, amino acids, and other carbon sources that might be available in marine waters. Methylotrophic organisms have been isolated from environments with similar carbon sources (11). Both isolates grew well over broad ranges of salinities and mesophilic temperatures. The ability to flourish under a wide range of growth conditions and the ability to utilize a variety of substrates are probably characteristics of organisms adapted to rapidly changing environmental conditions (2), such as those typical of salt marshes, where large fluctuations in salinity, temperature, and substrate availability are common.

Both isolates had blebs on their surfaces that appeared to be formed from the outer membrane. Similar membrane structures have been described for other gram-negative and grampositive bacteria $(1,9,12)$. In a gram-negative rumen bacterium, cellulose and xylanase activities were associated with the vesicles (9). The blebs and vesicles also increase the surface area of the cells by a factor of two, which might affect nutrient uptake. Although the function of the vesicles formed by IRE$31^{\mathrm{T}}$ and $\mathrm{KW}-40^{\mathrm{T}}$ is not known, these structures could be associated with the ability to grow in enrichment medium containing high levels of lignin and other wood-derived polymers. In the case of strain IRE-31 ${ }^{\mathrm{T}}$, the vesicles could also contain hydrolytic enzymes that may be protected inside.

Strains IRE- $31^{\mathrm{T}}$ and $\mathrm{KW}-40^{\mathrm{T}}$ are gram-negative, rod-shaped, strictly aerobic bacteria that require seawater-based medium for growth. The $16 \mathrm{~S}$ rRNA sequence analyses unambiguously placed these organisms in the $\gamma-3$ subclass of the Proteobacteria, which includes the fluorescent pseudomonads and related genera, the genera Oceanospirillum and Marinobacter, an Antarctic gas vacuolate bacterium (14), and the family Halomonadaceae $(7,10)$. However, the $16 \mathrm{~S}$ rRNAs of the new strains exhibited less than $91 \%$ sequence similarity with the $16 \mathrm{~S}$ rRNAs of all previously described members of this subclass, and phylogenetic analysis did not reveal any strong affinities with previously described members of this subclass. Likewise, there were sufficient phenotypic differences to support assignment of strains IRE- $31^{\mathrm{T}}$ and $\mathrm{KW}-40^{\mathrm{T}}$ to novel taxa. The $\mathrm{NaCl}$ and temperature requirements for growth exclude these organisms from the family Halomonadaceae and the genera Marinobacter and Oceanospirillum. Likewise, the $\mathrm{G}+\mathrm{C}$ contents are outside the range typical of the genera Alteromonas, Marinomonas, Marinobacter, and Oceanospirillum and, in the case of strain KW- $40^{\mathrm{T}}$, the pseudomonads. Strain IRE- $31^{\mathrm{T}}$ also differs from most Pseudomonas spp. in that it is not flagellated and it utilizes a limited number of carbohydrates (23).

The fatty acid profiles of IRE- $31^{\mathrm{T}}$ and $\mathrm{KW}-40^{\mathrm{T}}$ did not closely resemble the profiles of organisms previously characterized by the method used according to the microorganism identification system at Microbial ID, Inc. The fatty acid compositions most similar to strain IRE- $31^{\mathrm{T}}$ composition were those of Xanthomonas spp., and the fatty acid compositions most similar to the strain KW- $40^{\mathrm{T}}$ composition were those of Pseudomonas spp. However, the levels of similarity in both cases were very low.

It is also possible that the isolates resemble validly described species for which rRNA sequence and fatty acid data are not available: However, an examination of the genus descriptions that might include such species failed to identify any genus with a high level of phenotypic similarity to the isolates. Thus, 
we concluded that isolates IRE- $31^{\mathrm{T}}$ and $\mathrm{KW}-40^{\mathrm{T}}$ represent novel genera and species.

Description of Microbulbifer gen. nov. Microbulbifer (Mi.cro. bul'bi.fer. Gr. adj. micro, small; L. m. n. bulbus, onion, bulb; L. suff. -fer, carrying, bearing; L. m. n. Microbulbifer, small bearer of bulbs). Cells are rod shaped, gram negative, strictly aerobic, and oxidase and catalase positive. The cell envelope has numerous surface vesicles derived from the outer membrane. Grows on sugars, fatty acids, and amino acids. Requires sea salt-based medium for growth. The type species is Microbulbifer hydrolyticus.

Description of Microbulbifer hydrolyticus sp. nov. Microbulbifer hydrolyticus (hy.dro.ly'ti.cus. Gr. n. hydor, water; Gr. adj. lytikos, dissolving, splitting; M. L. adj. hydrolyticus, splitting with [by] water, referring to the hydrolytic activity of the bacterium). The cells of type strain IRE-31 are rod shaped (1.1 to $1.7 \mu \mathrm{m}$ long and 0.3 to $0.5 \mu \mathrm{m}$ wide in exponential-phase growth in glucose medium) and have numerous vesicles on their surfaces. Cells are gram negative and nonmotile. Colonies on marine agar 2216 are cream colored.

The temperature range for growth is 10 to $41^{\circ} \mathrm{C}$, and optimal growth occurs at $37^{\circ} \mathrm{C}$. The $\mathrm{NaCl}$ range for growth is 0.1 to 1 $\mathrm{M}$, and optimal growth occurs at $\mathrm{NaCl}$ concentrations between 0.1 and $0.5 \mathrm{M}$. The optimal $\mathrm{pH}$ is 7.5 , and the $\mathrm{pH}$ range is 6.5 to 8.5 . The organism is a strict aerobe and does not denitrify or accumulate polyhydroxybutyrate. It utilizes a limited number of carbohydrates and is able to grow only on glucose, xylose, $\mathrm{N}$-acetyl-D-glucosamine, and cellobiose. Amino acids and some aromatic compounds, such as vanillate and ferulate, are used. Exhibits oxidase, catalase, cellulase, xylanase, chitinase, gelatinase, amylase and Tweenase activities. Growth factors are not required, although a complex vitamin solution or a low concentration of yeast extract is stimulatory. Capsules are produced in liquid medium.

Cells are resistant to penicillin G, streptomycin, and vancomycin and susceptible to tetracycline, kanamycin, chloramphenicol, and ampicillin.

The $\mathrm{G}+\mathrm{C}$ content of the DNA as determined by high-performance liquid chromatography is $57.7 \mathrm{~mol} \%$. On the basis of its 16S rRNA sequence, IRE-31 ${ }^{\mathrm{T}}$ belongs to the $\gamma$ subclass of the Proteobacteria and forms a deep branch related to the pseudomonads sensu stricto. The organism was isolated from a marine enrichment community growing on pulp mill effluent as the sole carbon source. The original inoculum was from a salt marsh on the coast of Georgia. Type strain IRE-31 has been deposited in the American Type Culture Collection as strain ATCC 700072.

Description of Marinobacterium gen. nov. Marinobacterium (Ma.ri.no.bac.te'ri.um. L. adj. marinus, of the sea; Gr. neut. n. bakterion, a small rod; L. neut. n. Marinobacterium, marine rod). Cells are rod shaped and gram negative and have numerous vesicles on their surfaces. Strict aerobe. Oxidase and catalase positive. Grows on sugars, fatty acids, aromatic compounds, and amino acids. Requires sea salt-based medium for growth. The type species is Marinobacterium georgiense.

Description of Marinobacterium georgiense sp. nov. Marinobacterium georgiense (ge.or.gi.en'se. L. adj. georgiense, from Georgia, the place where the organism was isolated). Cells of type strain $\mathrm{KW}-40$ are rod shaped (1.6 to $2.3 \mu \mathrm{m}$ long and 0.5 to $0.7 \mu \mathrm{m}$ wide in exponential-phase growth in glucose medium) and have numerous vesicles on their surfaces. Has a polar flagellum, fimbriae, and a typical S-layer. Cells are gram negative and motile. Colonies on marine agar 2216 are translucent.

The temperature range for growth is 4 to $41^{\circ} \mathrm{C}$, and optimal growth occurs at $37^{\circ} \mathrm{C}$. The $\mathrm{NaCl}$ range for growth is 0.01 to 2
$\mathrm{M}$, and optimal growth occurs at $\mathrm{NaCl}$ concentrations between 0.1 and $0.5 \mathrm{M}$. The optimal $\mathrm{pH}$ is 7.5 , and the $\mathrm{pH}$ range is 5.5 to 9.5 . KW- $40^{\mathrm{T}}$ is a strict aerobe, does not denitrify, and does not accumulate polyhydroxybutyrate. The sole carbon sources utilized include some carbohydrates and amino acids, as well as aromatic compounds, such as phenol, benzoate, and $p$-hydroxybenzoate, and lignin-related compounds, such as $p$-coumarate, cinnamate, ferulate, and vanillate. Methanol and formate are utilized, but methylamine is not utilized. The alcohols utilized include ethanol, 1-propanol, 2-propanol, and 1-butanol. Exhibits oxidase, catalase, and Tweenase activities. Growth factors are not required, although a complex vitamin solution or yeast extract stimulates growth.

Cells are resistant to penicillin $G$ and vancomycin and susceptible to tetracycline, streptomycin, kanamycin, chloramphenicol, and ampicillin.

The $\mathrm{G}+\mathrm{C}$ content of the DNA is $54.9 \mathrm{~mol} \%$. On the basis of its 16S rRNA sequence, KW- $40^{\mathrm{T}}$ belongs to the $\gamma$ subclass of the Proteobacteria, forming a deep branch related to the pseudomonads sensu stricto. The organism was isolated from a marine enrichment community growing on pulp mill effluent as the sole carbon source. The original inoculum was from a salt marsh on the coast of Georgia. Type strain KW-40 has been deposited in the American Type Culture Collection as strain ATCC 700074

\section{ACKNOWLEDGMENTS}

This work was supported in part by a predoctoral fellowship (to J.M.G.) from the local government of the Canary Islands, Spain. Funds were also provided by Office of Naval Research grant NOOO14-91-J1826 and USGS Water Research Institute Program grant RR50824F.

\section{REFERENCES}

1. Antranikian, G., C. Herzberg, F. Mayer, and G. Gottschalk. 1987. Change in the cell envelope structure of Clostridium sp. strain EM1 during massive production of $\alpha$-amylase and pullulanase. FEMS Microbiol. Lett. 41:193197.

2. Atlas, R. M., A. Horowitz, M. Krichevsky, and A. K. Bej. 1991. Response of microbial populations to environmental disturbances. Microb. Ecol. 22:249256

3. Baumann, P., and L. Baumann. 1981. The marine Gram-negative eubacteria: genera Photobacterium, Beneckea, Alteromonas, Pseudomonas, and Alcaligenes, p. 1302-1331. In M. P. Starr, H. Stolp, H. G. Trüper, A. Balows, and H. G. Schlegel (ed.), The prokaryotes. Springer-Verlag, Berlin, Germany.

4. Benner, R., M. A. Moran, and R. E. Hodson. 1986. Biogeochemical cycling of lignocellulosic carbon in marine and freshwater ecosystems: relative contributions of procaryotes and eucaryotes. Limnol. Oceanogr. 31:89-100.

5. Britschgi, T. B., and R. D. Fallon. 1994. PCR-amplification of mixed $16 \mathrm{~S}$ rRNA genes from an anaerobic, cyanide-degrading consortium. FEMS Microbiol. Ecol. 13:225-232.

6. Daniels, L., R. S. Hanson, and J. A. Phillips. 1994. Chemical analysis, p. 512-554. In P. Gerhardt, R. G. E. Murray, W. A. Wood, and N. R. Krieg (ed.), Methods for general and molecular bacteriology. American Society for Microbiology, Washington, D.C.

7. Dobson, S. J., T. A. McMeekin, and P. D. Franzmann. 1993. Phylogenetic relationships between some members of the genera Deleya, Halomonas, and Halovibrio. Int. J. Syst. Bacteriol. 43:665-673.

8. Felsenstein, J. 1989. PHYLIP-phylogeny inference package (version 3.2) Cladistics 5:164-166.

9. Forsberg, C. W., T. J. Beveridge, and A. Hellstrom. 1981. Cellulase and xylanase release from Bacteroides succinogenes and its importance in the rumen environment. Appl. Environ. Microbiol. 42:886-896.

10. Franzmann, P. D., U. Wehmeyer, and E. Stackebrandt. 1988. Halomonadaceae fam. nov., a new family of the class Proteobacteria to accommodate the genera Halomonas and Deleya. Syst. Appl. Microbiol. 11:16-19.

11. Fulthorpe, R. R., S. N. Liss, and D. G. Allen. 1993. Characterization of bacteria isolated from a bleached kraft pulp mill wastewater treatment plant. Can. J. Microbiol. 39:13-24.

12. Gauthier, M. J., B. Lafay, R. Christen, L. Fernandez, M. Acquaviva, P. Bonin, and J.-C. Bertrand. 1992. Marinobacter hydrocarbonoclasticus gen. nov., sp. nov., a new, extremely halotolerant, hydrocarbon-degrading marine bacterium. Int. J. Syst. Bacteriol. 42:568-576.

13. González, J. M., W. B. Whitman, R. E. Hodson, and M. A. Moran. 1996. 
Identifying numerically abundant culturable bacteria from complex communities: an example from a lignin enrichment culture. Appl. Environ. Microbiol. 62:4433-4440.

14. Gosink, J. J., and J. T. Staley. 1995. Biodiversity of gas vacuolate bacteria from antarctic sea ice and water. Appl. Environ. Microbiol. 61:3486-3489.

15. Hobbie, J. E., R. J. Daley, and S. Jasper. 1977. Use of Nuclepore filters for counting bacteria by fluorescence microscopy. Appl. Environ. Microbiol. 33:1225-1228.

16. Kovacs, N. 1956. Identification of Pseudomonas pyocyanea by the oxidase reaction. Nature (London) 178:703.

17. Laddaga, R., and R. A. McLeod. 1982. Factors affecting the lytic susceptibility of marine and terrestrial bacteria. Can. J. Microbiol. 28:414-424.

18. Lane, D. J., B. Pace, G. J. Olsen, D. A. Stahl, M. L. Sogin, and N. R. Pace. 1985. Rapid determination of 16S ribosomal RNA sequences for phylogenetic analyses. Proc. Natl. Acad. Sci. USA 82:6955-6959.

19. Ledyard, K. M., E. F. DeLong, and J. W. H. Dacey. 1993. Characterization of a DMSP-degrading bacterial isolate from the Sargasso Sea. Arch. Microbiol. 160:312-318

20. Mesbah, M., U. Premachandran, and W. B. Whitman. 1989. Precise measurement of the $\mathrm{G}+\mathrm{C}$ content of deoxyribonucleic acid by high-performance liquid chromatography. Int. J. Syst. Bacteriol. 39:159-167.

21. Murray, R. G. E., R. N. Doetsch, and C. F. Robinow. 1994. Determinative and cytological light microscopy, p. 21-41. In P. Gerhardt, R. G. E. Murray, W. A. Wood, and N. R. Krieg (ed.), Methods for general and molecular bacteriology. American Society for Microbiology, Washington, D.C.

22. Olsen, G. J., C. R. Woese, and R. Overbeek. 1994. The winds of (evolutionary) change: breathing new life into microbiology. J. Bacteriol. 176:1-6.

23. Palleroni, N. J. 1984. Genus I. Pseudomonas, p. 141-199. In N. R. Krieg and J. G. Holt (ed.), Bergey's manual of systematic bacteriology, vol. 1. Williams \& Wilkins Co., Baltimore, Md.

24. Rayman, M. K., and R. A. McLeod. 1975. Interaction of $\mathrm{Mg}^{2+}$ with peptidoglycan and its relation to the prevention of lysis of a marine pseudomonad. J. Bacteriol. 122:650-659.

25. Robinson, D. G., U. Ehlers, R. Herken, B. Herrmann, F. Mayer, and F.-W. Schürmann. 1987. Methods of preparation for electron microscopy-an introduction for the biomedical sciences. Springer-Verlag, Berlin, Germany.

26. Shiba, T. 1992 . The genus Roseobacter, p. 2156-2159. In M. P. Starr, H.
Stolp, H. G. Trüper, A. Balows, and H. G. Schlegel (ed.), The prokaryotes. Springer-Verlag, Berlin, Germany.

27. Singh, A. P., and J. A. Butcher. 1991. Bacterial degradation of wood cell walls: a review of degradation patterns. J. Inst. Wood Sci. 12:143-157.

28. Singh, A. P., T. Nilsson, and G. F. Daniel. 1990. Bacterial attack of Pinus sylvestris wood under near anaerobic conditions. J. Inst. Wood Sci. 11:237249.

29. Skipper, N., M. Sutherland, R. W. Davies, D. Kilburn, R. C. Miller, Jr., A. Warren, and R. Wong. 1985. Secretion of a bacterial cellulase by yeast. Science 230:958-960.

30. Smibert, R. M., and N. R. Krieg. 1981. General characterization, p. 124. In P. Gerhardt, R. G. E. Murray, R. N. Costilow, E. W. Nester, W. A. Wood, N. R. Krieg, and G. B. Phillips (ed.), Manual of methods for general bacteriology. American Society for Microbiology, Washington, D.C.

31. Stahi, D. A., and R. I. Amann. 1991. Development and application of nucleic acid probes in bacterial systematics, p. 205-248. In E. Stackebrandt and M. Goodfellow (ed.), Nucleic acid techniques in bacterial systematics. John Wiley \& Sons Ltd., Chichester, England.

32. Swofford, D. 1990. PAUP: phylogenetic analysis using parsimony, version 3.0. Illinois Natural History Survey, Champaign.

33. Takeuchi, M., H. Sawada, H. Oyaizu, and A. Yokota. 1994. Phylogenetic evidence for Sphingomonas and Rhizomonas as nonphotosynthetic members of the alpha-4 subclass of the Proteobacteria. Int. J. Syst. Bacteriol. 44:308 314.

34. Tsai, Y.-L., and B. H. Olson. 1991. Rapid method for direct extraction of DNA from soil and sediments. Appl. Environ. Microbiol. 57:1070-1074.

35. Van der Peer, Y., J.-M. Neefs, and R. De Wachter. 1990. Small ribosomal subunit RNA sequences, evolutionary relationships among different life forms, and mitochondrial origins. J. Mol. Evol. 30:463-476.

36. Vicuña, R. 1988. Bacterial degradation of lignin. Enzyme Microb. Technol. 10:646-655.

37. Widdel, F., G.-W. Kohring, and F. Mayer. 1983. Studies on dissimilatory sulfate-reducing bacteria that decompose fatty acids. III. Characterization of the filamentous gliding Desulfonema limicola gen. nov., sp. nov., and Desulfonema magnum sp. nov. Arch. Microbiol. 134:286-294.

38. Woese, C. R. 1987. Bacterial evolution. Microbiol. Rev. 51:221-271.

39. Zimmermann, W. 1990. Degradation of lignin by bacteria. J. Biotechnol. 13:119-130. 